\title{
HOW GOES THE BATTLE? \\ AN EXPLORATION OF GUARDIANSHIP REFORM
}

\author{
DOUG SURTEES
}

This article attempts to evaluate the success of guardianship law reform in Saskatchewan through a study of 446 guardianship applications made since the 2001 enactment of The Adult Guardianship and Codecision-making Act. It begins by providing a brief history of guardianship law and details the development of the modern legislation. The author examines granted guardianship orders and surveys participants in the guardianship process in order to determine if the principles underlying the modern legislation have been upheld by the courts.
Cet article tente d'évaluer le succès de la réforme de la loi sur la tutelle en Saskatchewan au moyen de l'étude de 446 demandes de tutelle faites depuis l'adoption en 2001 de la Loi sur la tutelle et la prise de codécisions (Adult Guardianship and Co-decisionmaking Act). L'article début par un bref historique de la loi sur la tutelle et des détails sur l'élaboration de la loi moderne. L'auteur examine les ordonnances de tutelle accordées et interrogent les participants au processus de tutelle dans le but de déterminer si les cours ont maintenu les principes sous-jacents à la loi moderne.

\section{TABLE OF CONTENTS}

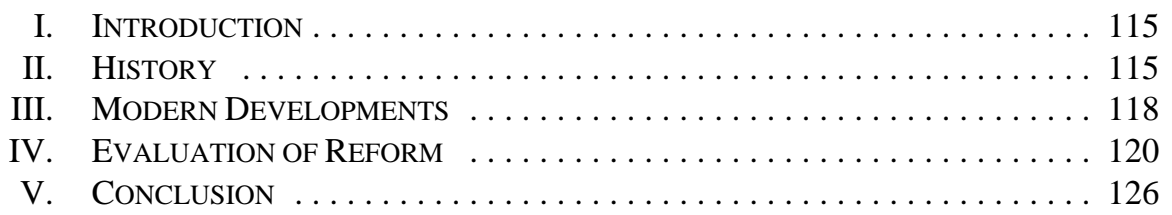

\section{INTRODUCTION}

There are a variety of legal mechanisms that empower one individual to make decisions on behalf of another. This occurs, for example, when one executes a power of attorney or an agency agreement. "Guardianship” is a legal concept that allows one person to act as a substitute decision-maker for another. Guardianship is used after a loss of capacity when an adult who is living in the community has lost capacity and has not otherwise provided for their incapacity. ${ }^{1}$ This distinguishes guardianship from other legal mechanisms that permit one person to make a decision on behalf of another. In this article, I trace the modern development of guardianship law generally, and then examine how well one jurisdiction's reforms have met the reformers' objectives. While the jurisdiction examined is Saskatchewan, the reformers' objectives are commonplace in modern guardianship law. There is no reason to assume results would differ elsewhere.

\section{HISTORY}

When guardianship is applied to adults (as opposed to children), the law has historically made a distinction between individuals who have lost legal capacity and those who never had legal capacity. This distinction is ancient; the earliest written record of it in English law appears to be the mysterious Statute De Praerogativa Regis. ${ }^{2}$ The Praerogativa Regis, 
however, did not create this distinction, nor did it create the ability of the king to take control over the ward's property.

In feudal times, the lord of the manor originally took charge of the property of any person of unsound mind. Through some unknown developments, the king acquired this right around the end of the reign of Henry III (who reigned 28 October 1216 to 16 November 1272). ${ }^{3}$ The Crown's prerogative in this regard was described in Fleta. ${ }^{4}$ Fleta is a treatise written in Latin by an unknown author. It is based upon an earlier treatise written in French by Bracton. ${ }^{5}$ Both treatises furthered the King's preferred legal theory that the king is the sole fountain of justice, and the king's courts and officials are necessary to carry out the king's responsibility of dispensing justice. In fact, the thirteenth century generally was a period of expansion of the king's courts, as they replaced the pre-existing traditional structure. ${ }^{6}$ Fleta was written around $1290^{7}$ and referred to the king's prerogative regarding wardship of the lands and person of those who were found to lack capacity. ${ }^{8}$ The earlier treatise by Bracton did not refer to the king's jurisdiction over the incapacitated. ${ }^{9}$

Individuals who were once seen as competent, but who had lost their competence were called "lunatics" or referred to as "non compos mentis."10 Those who were seen as never having been competent were known as "natural fools" or "idiots." "Fleta declares the king's prerogative right over the person and estates of both those known as natural fools or idiots, and lunatics or individuals found to be non compos mentis. ${ }^{12}$ Fleta indicates that prior to this assertion of jurisdiction, people called tutores or "tutors," presumed to be the lords of whom the ward held lands, traditionally exercised custody over the property of idiots. ${ }^{13}$ Fleta says this change came about as a result of an act passed during the reign of Edward I (20 November 1272 to 7 July 1307) to empower the king in this regard, due to abuses committed by the tutors. ${ }^{14}$ Holdsworth, as mentioned above, suggests this change came about during the reign of Henry III. ${ }^{15}$ Regardless of exactly when the change occurred, and regardless of whether it occurred to protect wards from the abuses of their overlords or to extend the king's reach into this profitable area of the law, by the late thirteenth century, the king had assumed jurisdiction over adults who lacked capacity.

Sir William Holdsworth, A History of English Law, 7th ed by AL Goodhart \& HG Hanbury (London, UK: Methuen \& Co, Sweet \& Maxwell, 1956) vol 1 at 473.

Ibid.

Theodore FT Plucknett, A Concise History of the Common Law, 5th ed (London, UK: Butterworth \& Co, 1956) at 265.

Ibid at 80, stating: "One thing at least is very clear, namely, that the royal courts were intruders upon ground which had been occupied for centuries by older jurisdictions, and that the authority of these older jurisdictions was original and in no way derived from the Crown. This undoubted historical fact begins to be obscured by legal theory in the twelfth, and still more in the thirteenth centuries.”

Ibid at 81 .

Holdsworth, supra note 3 at 473.

Theodore FT Plucknett, A Concise History of the Common Law, 2d ed (Rochester, NY: The Lawyers Co-operative, 1936) at 231, says of Bracton: "His great book was never finished, for he seems to have stopped working on it in 1256."

Sir William Blackstone, Commentaries on the Laws of England, vol 1 (Philadelphia: Robert Bell, 1771) at 304.

Ibid at 302.

John Reeves, History of the English Law From the Time of the Saxons to the End of the Reign of Philip and Mary, 2d ed (New York: Augustus M Kelley, 1969) vol 2 at 307-308. See also Holdsworth, supra note 3 at 473-74.

Reeves, ibid; Holdsworth, ibid at 473.

Reeves, ibid at 308.

Holdsworth, supra note 3 at 473. 
Legal historian Theodore Plucknett concluded that the Praerogativa Regis was not, in fact, a statute, but was what he called an "unofficial tract ... which later ages sometimes mistook for a statute" ${ }^{16}$ Plucknett acknowledges, however, that it is possible the document was an official summary of the King's prerogatives as exercised in chancery. ${ }^{17}$ Whether statute or otherwise, however, it is clear that the Praerogativa Regis was created in England between 1255 and 1290. It recorded, rather than created, the king's prerogative powers over individuals who lacked capacity.

Individuals found to be non compos mentis included those who would have lucid intervals. These individuals, whether they had lucid intervals or not, were treated by the law as having the possibility of regaining competency. If they did, they would be entitled to retake their property. ${ }^{18}$ As a result, the concept began to develop that a guardian should manage the property of the non compos mentis individual (who was called a "ward") on the ward's behalf.

Those who lacked capacity from birth, the so-called "natural fools" or "idiots," were treated differently. ${ }^{19}$ The profits from their estates became the king's property, subject only to the king's duty to provide the ward with necessaries. The guardianship of idiots was originally a valuable right for the king. It was, until the eighteenth century, a source of royal revenue. ${ }^{20}$ Jurisdiction over this right was first vested in the Exchequer, but over time its exercise came to be seen as a duty and jurisdiction passed to the Chancellor. ${ }^{21}$ Eventually, guardians of the estates of idiots were held to the same standards as guardians of the estates of those found to be non compos mentis. ${ }^{22}$

In 1890, the English Parliament passed the Lunacy Act, $1890 .^{23}$ This made it possible for a judge to declare an individual incompetent based on affidavit evidence. ${ }^{24}$ The 1890 Act and its successors were known collectively as the English "lunacy laws.” Modern guardianship laws in Canada and other common law jurisdictions were, until fairly recently, based on these

"Blackstone mentions the income of idiots' estates as a source of revenue; but the 'clemency of the crown and the pity of the juries' gradually assimilated the condition of idiots to that of lunatics": ibid at 474 [footnote omitted].

1890 (UK), 53 \& 54 Vict, c 5.

"The Lunacy Act of 1890 amended De Prerogativa Regis, facilitated disposal of land and dispensed the formal hearing, allowing a judge to declare incompetence based on affidavit evidence": NJ Marlett, Issues of Competence and the Dependent Adults Act: Guidelines and Proposed Report Forms (Office of the Public Guardian: Alberta Social Service and Community Health, 1980) at 2. 
laws. ${ }^{25}$ The development of guardianship law in this way privileged the protection of property over the protection of the person. The rationale behind the English lunacy laws was that the ward's property should be managed so that it could be returned to the ward if capacity was regained.

\section{MODERN DEVELOPMENTS}

The law generally began to benefit from developments in psychology in the late nineteenth century. For example, in 1870, Banks v. Goodfellow ${ }^{26}$ rewrote our understanding of testamentary capacity. In that case, Chief Justice Cockburn said: "The pathology of mental disease and the experience of insanity in its various forms teach us that while, on the one hand, all the faculties, moral and intellectual, may be involved in one common ruin, as in the case of the raving maniac, in other instances one or more only of these faculties or functions may be disordered." ${ }^{27}$ The law began to reject the view of capacity as a single attribute that an individual either possessed or did not. The law recognized that an individual may have capacity to do some things (such as marry or enter a contract) but not to do other things (such as execute a will).

These developments were slow to alter guardianship law. Alberta passed legislation called the Dependent Adults Act ${ }^{28}$ (proclaimed in December 1978), which re-conceptualized guardianship law in Canada. This legislation changed the basis for awarding guardianship from a medical diagnosis (for example "adult has senility") to a conclusion of the adult's need (for example "adult is unable to care for himself"). The corollary of this reform was that the guardianship statute would no longer treat the need for a guardian as an "all or nothing" proposition. Plenary guardianship would be replaced by a guardianship structured to meet the individual needs of the adult. Other provinces followed in these changes, and the pace of reform accelerated. Saskatchewan, for example, had legislation based on the English lunacy laws until 1989. The 1989 Act, which like Alberta's legislation was called the Dependent Adults $\mathrm{Act}^{29}$ was itself replaced in 2001. The 2001 legislation, called The Adult Guardianship and Co-decision-making Act, ${ }^{30}$ was passed following extensive consultation between various provincial government departments and community groups. A steering committee was formed to make recommendations regarding the abuse of adults in vulnerable circumstances. The Steering Committee on the Abuse of Adults in Vulnerable Circumstances (Steering Committee) recommended mandatory periodic review of guardianship orders and the creation of temporary guardianship orders for emergency situations. ${ }^{31}$ While the 2001

25 "In all but three provinces, the origins of the existing provincial and territorial statutes affecting judicial determination of incapacity or incompetency, and the appointment of guardians can be traced to 19th century English lunacy law”: Robert M Gordon \& Simon N Verdun-Jones, Adult Guardianship Law in Canada (Scarborough: Carswell, 1992) at 1-16 [footnote omitted]. The three provinces Gordon refers to are Alberta, Saskatchewan, and Quebec.

(1870), LR 5 QB 549.

Ibid at 560 .

SA 1976 , с 63.

SS 1989-90, с D-25.1.

SS 2000, с A-5.3 [AGCA].

Sask, Steering Committee on the Abuse of Adults in Vulnerable Circumstances, Report and Recommendations (December 1997), online: Government of Saskatchewan <http://www.justice. gov.sk.ca/vasc > at 27 [Steering Committee, Report]. 
legislation does not require mandatory periodic review of guardianship orders, ${ }^{32}$ it does provide for temporary guardianship to be ordered. The Steering Committee also reported two problems with the administration of the then current legislation. Despite the legislative rejection of universal plenary guardianship in Saskatchewan in 1989, the Steering Committee said: "It appears that judges often grant total guardianship without considering whether less intrusive partial guardianship powers may be effective.”33 The Steering Committee also said: "It appears that judges often do not require that alleged dependent adults are served with guardianship applications; it was suggested that it should only be in exceptional circumstances that service is waived." 34 These two concerns could be phrased as objectives as follows:

1. To ensure that adults who were the subject of the application received notice of the application prior to the hearing; and

2. To ensure that the orders granted reflect the least restrictive order that is sufficient to meet the adult's needs principle. The co-decision-making option that was added to the legislation becomes an additional means of fulfiling this principle.

The 2001 legislation addressed both of these criticisms and provided a formal structure for the process of co-decision-making. The objective of ensuring that the adult who is the subject of the order receives notice of the proceedings is a critically important one, however my research does not identify whether or not the court is meeting this objective. The legislation provides that a judge can dispense with providing notice to those entitled to receive it. ${ }^{35}$ In the case of an adult who is the subject of the application, however, the legislation provides that "the court shall not dispense with service on the adult unless it is satisfied, on the basis of sufficient medical evidence, that special circumstances exist and service would be injurious to the adult and contrary to the best interests of the adult." ${ }^{\text {"6 }}$ In 446 applications, notice to the adult who was the subject of the order was dispensed with 169 times (37.9 percent of the time).

Co-decision-making is a process that is less intrusive than guardianship, and that allows an individual to be appointed to assist adults in coming to their own decisions. Saskatchewan's 2001 legislation was seen as a large step towards achieving a guardianship regime that imposes the least restrictive order that is sufficient to meet the adult's need. ${ }^{37}$ This principle is routinely touted as a fundamental goal of guardianship legislation. The addition of a co-decision-making (sometimes called “supported decision making”) alternative to guardianship is less common, but would seem to further the "the most effective, but the least restrictive and intrusive order” principle.

\footnotetext{
32 Although the legislation does not require mandatory review of orders, a review was ordered by the judge in 63 out of the 446 applications.

Steering Committee, Report, supra note 31 at 27.

Ibid.

AGCA, supra note 30 at s 11(1)(a).

Ibid, s 11(2).

For a review of the development of co-decision-making in Saskatchewan see Doug Surtees, "The
} Evolution of Co-Decision-Making in Saskatchewan” (2010) 73:1 Sask L Rev 75. 


\section{EVALUATION OF REFORM}

The discussion of future guardianship reform ought to be informed by an evaluation of previous reform. So, how successful has the Saskatchewan reform been? Evaluating the success of law reform is a complicated process. It is difficult to identify changed outcomes or behaviors. Even if such outcomes or behaviors are identified, we are usually not sure the new outcome was, in fact, caused by the change in legislation - it may have been caused by any of a myriad of other critical social forces. For example, conventional wisdom tells us that the apparent reduction in the number of individuals driving while impaired ("occurrences") is correlated with the increase in the severity and enforcement of impaired driving legislation (“enforcement”). Even if true, this correlation does not tell us whether more enforcement caused a drop in occurrences, whether a drop in occurrences created conditions that resulted in more enforcement, or whether some third variable caused a new social intolerance for driving while impaired, resulting in a lower number of occurrences and a call for more enforcement.

Despite the difficulty in determining the precise effects of legislative change, examining data collected from guardianship and co-decision-making applications will provide some insight into whether or not the enlightened principle that adults are entitled to receive the most effective, but least intrusive, order is being reflected in the practice of obtaining guardianship orders. To that end, I have reviewed guardianship orders granted under Saskatchewan's current guardianship legislation and surveyed some of the participants in the guardianship process. ${ }^{38}$ Saskatchewan's current guardianship legislation became effective 15 July 2001. Between that date and the summer of 2008, 529 applications for guardianship were filed with the Public Guardian and Trustee's office. ${ }^{39}$ Of the 529 applications, 446 files were reviewed. ${ }^{40}$ During the summers of 2008 and 2009, my research assistants combed through all 446 applications. They manually recorded data from each of the 446 files reviewed on a unique information collection form. This raw data was then converted to an electronic format and finally analyzed for correlations. ${ }^{41}$ As a follow-up to this research, I sent a survey to each of the lawyers listed as "lawyer in charge of file" on at least one application. A total of 34 lawyers responded. ${ }^{42}$

The drafters of the 2001 legislation provided a set of principles to guide the interpretation and administration of the guardianship legislation. These principles address the Steering Committee's concerns regarding hearings proceeding without notice to the subject and their

I would like to thank the Law Foundation of Saskatchewan for their financial support of this project. These findings have been previously reported to the Law Foundation of Saskatchewan. Ethical approval was granted by the University of Saskatchewan Behavioural Research Ethics Board [Beh\#: 09-148a]. Filing with the Public Guardian and Trustee's office is required under Saskatchewan legislation.

The difference is made up of files which had been closed and "culled," so that they were no longer stored with the remaining active and closed files. In other words, they had been closed and mixed in with other Public Guardian and Trustee files, so that they became difficult to access. There appears to be nothing about these files which would be any different than the 446 that were accessible, so the decision was made to exclude the "difficult to access" files. The inability to access this modest number of files should not have affected the results of the study.

41 The program used was a Statistical Package for the Social Sciences (SPSS) database.

42 A total of 234 lawyers were identified as lawyers in charge of at least one file. I was unable to locate 34 of these lawyers, seven expressly declined to participate, and ten were identified as either temporarily or permanently no longer practicing law. The survey was sent to the remaining 183 lawyers. Thirty-four returned the survey. This is a return rate of 19 percent. 
concern over plenary or overinclusive orders. The AGCA states that the legislation must be both interpreted and administered in compliance with these principles:

(a) adults are entitled to have their best interests given paramount consideration;

(b) adults are entitled to be presumed to have capacity, unless the contrary is demonstrated;

(c) adults are entitled to choose the manner in which they live and to accept or refuse support, assistance or protection, as long as they do not harm themselves or others and have the capacity to make decisions about those matters;

(d) adults are entitled to receive the most effective, but the least restrictive and intrusive, form of support, assistance or protection, when they are unable to care for themselves or their estates;

(e) adults who have difficulty communicating because of physical or mental disabilities are entitled to communicate by any means that enables them to be understood;

(f) adults are entitled to be informed about and, to the best of their ability, participate in, decisions affecting them. ${ }^{43}$

These principles are interrelated and reflect an "autonomy" model (as opposed to a "best interests” model) of guardianship and co-decision-making. Saskatchewan’s long standing commitment to the autonomy model is reflected by the statement of a former chair of the Saskatchewan Law Reform Commission back in 1981: "One of the purposes of a "tailormade’ personal guardianship order is to protect the protected from being over-protected.”44

It is my thesis that substantive guardianship reform, such as occurred in Saskatchewan in 2001, while appearing to provide substantially greater legislative protection of rights of adults subject to the process, actually results in, at best, only small incremental change. There is no reason to believe that the Saskatchewan experience related to the 2001 legislation is different than would be experienced in any other jurisdiction. I base my conclusion that the legislation has resulted in only incremental substantive change on my finding that guardianship orders issued under the 2001 legislation appear to be crafted as virtually plenary orders in the overwhelming majority of cases. Saskatchewan's progressive guardianship and co-decision-making legislation, at present, does not appear to deliver on its promise to provide its citizens with the most effective, but the least restrictive and intrusive form of support, assistance, and protection.

It appears that the vast majority of orders granted under the 2001 legislation remain virtually plenary orders. Fully 82 percent (398 out of 446) of all applications are for combined personal and property guardianship. The majority of these orders grant multiple 
powers. Out of a possible ten powers, ${ }^{45} 26$ percent (107 orders) grant all ten; 5.6 percent (23 orders) grant nine; 16.8 percent (69 orders) grant eight; and 15.8 percent grant seven (65 orders). Therefore, 64.2 percent of all orders contain seven or more of the possible ten powers. The powers most frequently omitted are the powers over employment, education, and determining whether or not the adult should apply for any licences or other consents ("licences”). Power over employment appears in 34 percent of orders (140 orders), power over education appears in 38 percent of orders (156 orders), and power over licences appears in 63 percent of orders (258 orders).

Clearly, most guardianship orders are, for all intents and purposes, plenary. It appears that many lawyers who make court applications for guardianship are unaware of the most effective, but least restrictive and intrusive principle. This general principle is fortified by specific rules in the legislation. Section 15 of the AGCA lists all the possible powers a court can award a personal co-decision-maker or a personal guardian. Section 14(1) authorizes the court to make the order granting powers to the personal co-decision-maker or guardian. This power in the court is limited by section 14(2), which prohibits a court from making such an order "unless alternative ways to assist the adult in making decisions with respect to matters relating to his or her person, including less intrusive forms of support or assistance in decision-making, have been tried or carefully considered." 46 The section also says the court shall not "give the personal co-decision-maker or personal guardian the authority to act with respect to all the matters mentioned in section 15 if an order providing particular powers would be sufficient to meet the needs of the adult." 47 So, in addition to violating the guiding principles, over-inclusive personal orders are contrary to the court's authority. The court's power with respect to property co-decision-makers and property guardians is also limited. The court is prohibited from making a property co-decision-maker or guardianship order unless "alternative ways to assist the adult in making decisions with respect to matters relating to his or her estate, including less intrusive forms of support or assistance in decision-making, have been tried or carefully considered." 48

Disappointingly, 18 of 34 lawyers surveyed (38 percent) indicated that they agreed with the statement: "An applicant should ask for powers they need as of the date of the application, and those which there is a reasonable likelihood they will need in the future, as

In addition to “other,” The Adult Guardianship and Co-decision-making Regulations, RRS, c. A-5.3 Reg 1, lists ten possible powers in the application form (Form H), and the draft order (Form N). These are:

$\checkmark$ decisions respecting the adult's living arrangements

decisions respecting access to the adult

decisions respecting the adult's social activities

decisions respecting the adult's employment

decisions respecting the adult's education, vocational or other training

$\square$ decisions respecting whether the adult should apply for any licence, permit, approval or other consent or authorization required by law that does not relate to the estate of the adult

$\checkmark$ decisions respecting legal proceedings that do not relate to the estate of the adult

$\square$ decisions respecting the adult's health care, including decisions respecting admission to a health care facility or respecting treatment of the adult

$\checkmark$ decisions respecting the restraint of the adult

$\square$ normal day-to-day decisions respecting the adult

$46 \quad$ Supra note 30, s 14(2)(a).

$47 \quad$ Ibid, s 14(2)(b).

Ibid, s 40(2)(a). 
this will reduce the need for further applications."49 Even more disappointing is the fact that another 13 lawyers agreed with the statement: “An applicant should ask for powers they need as of the date of the application, and those which there is a possibility they will need in the future, as this will reduce the need for further applications.” Both of these answers are clearly contrary to the principles of the legislation, particularly the most effective, but least restrictive and intrusive principle. Only three (less than 9 percent) of the lawyers surveyed agreed with the correct statement: "An applicant should only ask for powers which they need as of the date of the application.” Keep in mind that the surveyed lawyers had all been the lawyer in charge of an application under the legislation.

\section{Personal Powers Granted, Out of a Possible Ten Powers [COMBINED PERSONAL AND PROPERTY ORDERS]}

\begin{tabular}{|c|c|c|c|}
\hline Powers Granted (x/10) & Orders & Percentage & Ranking \\
\hline 10 & 107 & 26.9 & 1 \\
\hline 9 & 23 & 5.8 & 7 \\
\hline 8 & 69 & 17.3 & 2 \\
\hline 7 & 65 & 16.3 & 3 \\
\hline 6 & 45 & 11.3 & 4 \\
\hline 5 & 32 & 8 & 6 \\
\hline 4 & 37 & 9.3 & 5 \\
\hline 3 & 17 & 4.3 & 8 \\
\hline 2 & 3 & 0.8 & 9 \\
\hline 1 & 0 & 0 & 10 \\
\hline & 398 & $100 \%$ & \\
\hline
\end{tabular}

It bears mention that 30 orders were for co-decision-making. Sometimes these orders were combined with a guardianship order granting very specific powers to the guardian. Although 30 out of $441^{50}$ is a relatively low number (6.8 percent), I think the level of usage of the co-

49 The complete question posed to the lawyers was:

Which of the following statements most correctly sums up your view of guardianship applications:

1. An applicant should only ask for powers which they need as of the date of the application.

2. An applicant should ask for powers they need as of the date of the application, and those which there is a reasonable likelihood they will need in the future, as this will reduce the need for further applications.

3. An applicant should ask for powers they need as of the date of the application, and those which there is a possibility they will need in the future, as this will reduce the need for further applications. actually 441 individuals involved in the 446 applications. 
decision-making alternative is an encouraging beginning. Education of the bar appears to be necessary for co-decision-making to make greater inroads. Of the 34 lawyers who completed the survey, six (17 percent) indicated they were not sure how co-decision-making works. An additional seven (21 percent) indicated they would not recommend co-decision-making as an alternative. This is particularly strange considering that the most effective, but the least restrictive and intrusive principle would seem to require co-decision-making in appropriate cases. It would appear that at least 13 of the 34 responding lawyers (38 percent) were not discussing co-decision-making with their client.

These findings become more troubling when one considers the age of the subjects. Of the 395 adults for whom we had age data, the clear majority are older adults - the mean age at the date of application was 69.15 years. We also know that where incapacity is caused by infirmities associated with aging, loss of capacity typically occurs over time.

\section{Age Data of Guardianship Applications}

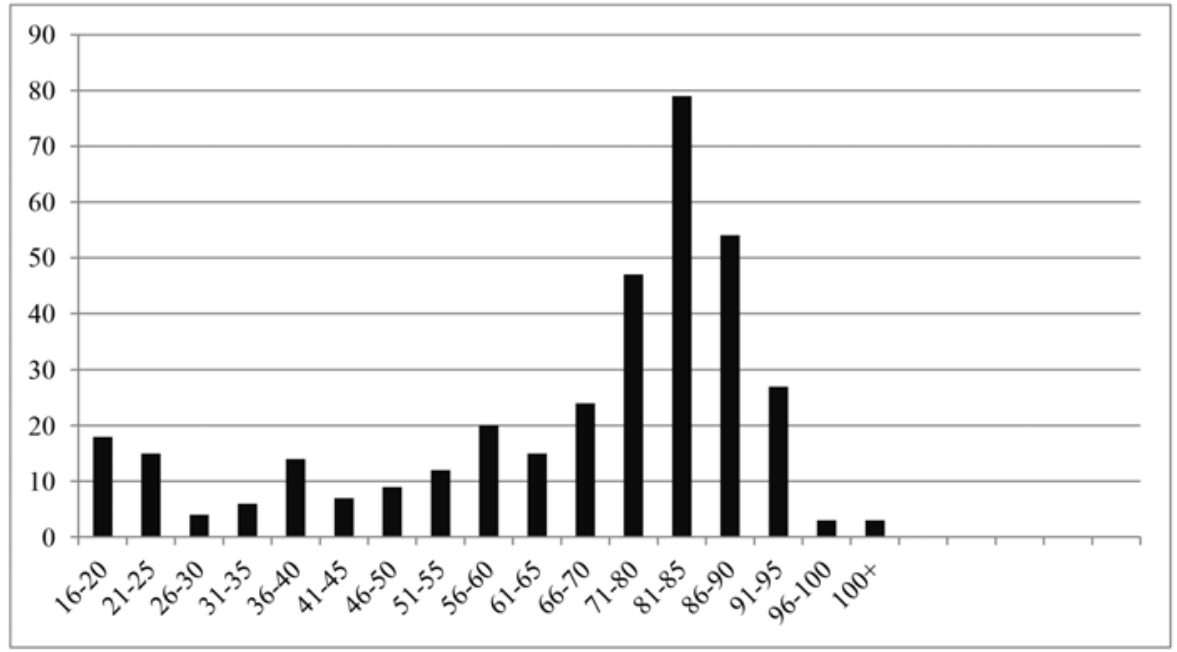

Age in Years

Note that the largest cohorts are 81-85, 86-90, 71-80, and 66-70. Only 25.6 percent of applications relate to someone under 60 years of age, while only 18.3 percent relate to someone under 50 years of age.

In addition, a number of adults who are subject to an order live in care facilities. Therefore, it appears that in many cases the powers that are not removed from the subject are powers that are extremely unlikely to ever be used by the subject (or the guardian, had they been removed). By way of example, one guardianship order for a 99 year old adult removed all powers from the adult, except for power over "decisions respecting the adult's employment” and “decisions respecting the adult's educational, vocational or other training." Presumably, this 99 year old would not be making any decisions regarding employment or 
training. This is, in all real senses of the word, a plenary order, effectively removing all the subject's decision making powers.

In total, 446 applications were reviewed. Of this number, only 42 were "repeat applications" that is, applications for an individual for which there had previously been an application. These 42 applications represented 37 individuals. Of these 37 individuals, one had two applications under this legislation and an order under the previous legislation. Of the remaining 36 individuals, four had two orders or applications under the current legislation, while 32 had an order under the previous legislation, followed by an application under the current legislation.

Of the 37 "repeat applicants," a review of the files indicates that 18 of the subsequent applications clearly did not seek or receive an increase in powers. These subsequent applications had a variety of other purposes. In two cases, the applicant simply made separate contemporaneous applications to appoint a property guardian and a personal guardian. In one case, the second application was simply a testamentary nomination. ${ }^{51}$ In one case, where the guardianship was all-inclusive, a second application was made to impose some limitations or conditions on the guardian's powers. The rest of these subsequent applications related to purposes such as a change in the individual who is the guardian, a change from temporary guardianship to permanent guardianship, or a continuation of the guardianship order in circumstances which indicate there was no increase in the guardians' powers.

In nine of the 37 cases, it is apparent that the subsequent application did result in more powers for the guardian. In four cases, this increase in powers was made where a temporary guardianship order was replaced by a permanent guardianship order. One of these was 30 days after the original temporary order. The remaining three were each approximately six months after the original temporary order. In all likelihood, the increase in power in these four cases is primarily due to the guardian learning what powers are required, rather than being due to diminishing capacity on the part of the adult subject. One subsequent application was to change a co-decision-making appointment to a guardianship appointment. Another saw a personal guardian appointed in the original order, followed by the appointment of a property guardian approximately six months later. The other subsequent applications in this category also added powers to the guardian. These are the types of changes which one would expect to see associated with the diminishing capacity of the adult subject.

In the remaining ten cases, the information on the file did not make it possible to discern whether the change brought about by the subsequent application resulted in additional powers being granted to the guardian. These can be thought of as “indeterminate files.” For example, the subsequent application may have been to appoint a new guardian, or to change a temporary guardianship into a permanent guardianship. Whatever the change to the applications in this category, there was insufficient information available on the file to determine if new powers had been added. In some cases, this was because the previous order

51 The legislation provides that “[a] decision-maker may nominate by will any person to act in that person's place as a decision-maker of the adult on the death of the decision-maker": AGCA, supra note 30, s 64(1). 
had been granted under the previous legislation or, for some other reason, did not form part of the file.

Therefore, out of 446 applications, only a maximum of 19 were to increase the powers of a guardian after the original order. As ten of these 19 files are actually indeterminate, the actual number is, in all likelihood, lower than this. Some or all of the ten indeterminate files are presumably files where no increase in guardianship power occurred. These 446 applications represent 441 individuals. ${ }^{52}$ If all 19 were actually subsequent applications to increase the powers of the guardian, this would represent 4.3 percent of applications. If only one-half of the ten indeterminate applications were not to increase guardianship power, the number would fall to 14 out of 441 , or 3.2 percent. If we exclude the indeterminate files, the number would change to nine out of 431, or 2 percent. Of this number, four of the applications which increased the powers are possibly explained by the guardian becoming more familiar with the needs of the adult, rather than by diminishing capacity of the subject of the guardianship. It would appear safe to conclude that it is an exceedingly rare event for the capacity of individuals who are subject to a guardianship order in Saskatchewan to diminish so as to require the guardian to seek more power.

\section{Conclusion}

I conclude that there are only two plausible explanations for the finding that the overwhelming majority of Saskatchewan guardianship orders, granted under the current legislation, appear to be crafted as virtually plenary orders. The first explanation is that in the overwhelming majority of cases, guardians continue to request, and courts continue to grant, orders that are unnecessarily plenary. If this is so, it is contrary to the legislation and the principles which are to guide its interpretation and administration. The specific principle being violated is the "least restrictive order that is sufficient to meet the adult's need" principle, although there is overlap with other principles as well. Indeed, if this explanation is correct, one must conclude that the legislation is not being correctly administered and that the sections of the legislation limiting the court's power to make orders are not being complied with. Perhaps one cause of this situation is a lack of knowledge on the part of the bench and the bar. Perhaps the built-in financial incentive applicants have in acquiring broader orders, likewise, plays a causal role. After all, applicants who are required to obtain successive orders will face increased transaction costs.

The other possible explanation is that the orders that are granted, despite their tendency to be virtually plenary orders are, in fact, the orders that are needed. It might be the case that these almost all-inclusive orders are the least restrictive orders that are sufficient to meet the adults' needs. If this explanation is correct, we have a separate problem. Outside of traumatic accident or acute medical events, loss of capacity typically does not occur all at once. We also know, however, that a great number of people with diminished capacity experience a diminishing of that capacity over time. Therefore, if the virtually plenary orders are appropriate, it must be the case that applicants are unnecessarily waiting too long before bringing an application.

52 This is because, as mentioned above, supra note 50, five individuals had two applications under this legislation. 
If guardians make the application at an appropriate time, and courts make the least restrictive order that is sufficient to meet the adult's need, we would expect to see a series of applications made for progressively more extensive orders. We do not. Adult guardianship needs continued reform. 